\title{
Living with Ongoing Political Trauma: The Prevalence and Impact of PTSD among Syrian Refugees*
}

\author{
Lina Haddad Kreidie \\ American University of Beirut, \\ Beirut, Lebanon
}

\author{
Mahmoud Kreidie \\ University of California, \\ California, USA
}

\author{
HayaAtassi \\ American University of Beirut, \\ Beirut, Lebanon
}

\begin{abstract}
Conflicts and wars kill humanity. Nationalist or Religious wars, terrorist attacks, shock and awe war on terror, and revolutions such as the Arab upheavals, all underscored by victors "mission accomplished": the destruction of the body, the soul, and the minds of people involved. This study addresses the prevalence and implications of Post-Traumatic Stress Disorder (PTSD) among civilians exposed to "continuous" trauma aggravated by displacement. The majority of the literature on PTSD that examines people who witnessed wars focuses mainly on veterans. Little research addresses the innocent populations caught up in an on-going political upheaval. Our case study includes 450 Syrian refugees 21 years or older living in Lebanon. The results found that $61.56 \%$ of the Syrian refugees met the criteria of full PTSD, $8.67 \%$ participants fit the criteria of partial PTSD, and $29.78 \%$ refugees did not report any symptoms of PTSD. PTSD affects the area of the brain responsible for executive function, including memory and emotional ability. Accordingly, we hypothesize that people with PTSD will be more prone to be conflictive, will have low impulse control, associated with anger and a high desire for revenge. Hence, high prevalence of PTSD among civilians feeds into the cycle of extremism and violence.
\end{abstract}

Keywords: continuous trauma, conflictive behavior, displacement, PTSD, Syrian refugees

\section{Introduction}

One serious side effect of political conflict and war is PTSD. Numerous studies looked at the impact of PTSD on war veterans or individuals directly involved or exposed to war (Galea, Nandi, \& Vlahov, 2005; Neria, Nandi, \& Galea, 2007; Norris et al., 2002). While most studies have focused on the prevalence and impact of PTSD on troops as a result of a single war incident, few consider the political impact of PTSD among civilians living in on-going conflict such as the Middle East region (Besser \& Neria, 2010; Neria et al., 2010). More important, political scientists rarely assess the neuro-biological importance of PTSD as a brain injury that impairs cognitive abilities of affected people (Pitman et al., 2012) and its consequent impact on social and political

\footnotetext{
*Acknowledgements: We thank our students at the American University of Beirut Anna Brenner, Yara Damaj, and Mayar Mnini for their role in the research survey questionnaire formulation, and very special thank you for Rama Kanj for her medical and neuroscience research contribution and comments. We also appreciate Yara Damaj and Fahed Hassan valuable effort in doing the SPSS statistical analysis. We owe Liya Kreidie and Natalija Trojanovic for their meticulous editing of the paper. Last but not least, we would like to extend our appreciation to Professor Kristen Renwick Monroe who have seen, reviewed and edited the work till the completion.

Lina Haddad Kreidie, Ph.D., Political Studies Public Administration Department, American University of Beirut.

Mahmoud Kreidie, M.D., F.A.A.N Clinical Professor, Neurology Department, University of California.

HayaAtassi, Political Studies Public Administration Department, American University of Beirut.
} 
behavior. Since recent medical literature confirms PTSD as an injury associated with deficits in regional brain volume (Karl et al., 2006), our study examines the neuro-psychiatric impact of PTSD, focusing on the contemporary Middle East, with its continuous trauma with violence, displacement, and terror associated with authoritarianism, religious sectarianism and extremism.

While considerable studies focus on the Israeli-Palestinian conflict, they do mostly on Israeli troops and civilians (Bleich, Gelkopf, \& Solomon, 2003; Gelkopf, Melamed, \& Solomon, 2008; Hobfoll, Canetti-Nisim, Johnson, Palmieri, Varley, \& Galea, 2008; Neria, Besse, Kiper, \& Westphal, 2010). The little research conducted on Palestinian population focuses mostly on children and youth (Thabet, Abed, \& Vostanis, 2004; Bar Tal, 2007; Barber, 2008; Dubaw et al., 2010). In line with this, even less research is conducted in other Middle Eastern countries that, likewise, suffer from continuous trauma induced by violence, displacement, captivity and torture (Farhood, Dimassi, \& Strauss, 2013; Farhood \& Dimassi, 2011; Karam et al., 2008; Macksoud \& Aber, 2008; Alyahri \& Goodman, 2008; Al-jawadi \& Abdul-Rahman, 2007; Qasrawi, Nabil, \& Shaheen, 2008; Gorst-Unsworth \& Goldenberg, 1998; Khamis, 2005; while only the following studies are done on Lebanon (Macksoud \& Aber, 1996; Farhood \& Damasi, 2011; Karam et al., 2008; Farhood, Dimassi, \& Straus, 2013).

In this study, we move beyond to explain the prevalence and impact of varying and continuous trauma on innocent populations caught up in war. Our case study is the Syrian refugees who flee civil war characterized by violence and destruction enticed by sectarianism, authoritarianism culminating by the terror of the Islamic State in the Levant (ISIL). We examine 450 Syrian refugees (50.9\% males and $49.1 \%$ females) 21 years or older living in Lebanon-mainly in poor areas making both Syrians and Lebanese partners in deprivation (Gebara, 2015). According to established clinical DSM IV criteria suggests that 277 (61.56\%) of the Syrian refugees met the criteria of full PTSD, 39 (8.67\%) participants fit the criteria of partial PTSD, and 134 (29.78\%) refugees did not report any symptoms of PTSD. Of those with PTSD, 24\% of were exposed to direct violence, with $41 \%$ state that those acts of violence have impacted their daily living activities. Almost all expressed political dissatisfaction with their treatment by political authorities, and virtually all believe life treated them unfairly. The study further delineates the consequence of low impulse control, anger, and revengeful behavior among those with PTSD signaling proneness for conflictive behavior. The significance of this alarming prevalence of PTSD lies in its collective impact on social and political behavior. We argue in this study that this neuropsychiatric injury that affects the brain, mainly in the area responsible for executive function, including memory and emotional ability, constitutes an important cognitive part of what we think of as humane action and moral choice. Accordingly, we hypothesize that people with PTSD are more prone to be conflictive and tend to have low impulse control, associated with anger along with a high sense of revenge against whom they perceive to be "the other". It is not that individuals with PTSD necessarily turn evil, but rather their ability to control their behavior and their cognitive ability could be tampered thereby affecting their ability to deal with issues peacefully at times of crisis. Ultimately, the impairment of the cognitive and emotional abilities of people with PTSD renders reconciliation quite difficult to achieve which in turn could feed into the cycle of violence.

The study proceeds in six sections. Part one defines and states the significance of PTSD as a neuropsychiatric injury. Part two reviews the literature on the prevalence and impact of PTSD. Part three delineates the history of the ongoing trauma Syrian refugees witnessed. Part four explains the methodology, and the data. Part five discusses the results of the interviews, Part six concludes and sets our recommendations on how to tackle such an alarming issue where the human waste is simply too great. 


\section{What Is PTSD?}

According to the Diagnostic Statistical Manual, fifth edition (DSM-5), PTSD is defined as a trauma-and-stress-related disorder that follows the experiencing or witnessing of a traumatic event, learning about its occurrence or repeatedly experiencing some of its aversive details (DSM-5, 2013). The criteria of PTSD in the DSM-5differ from the DSM-IV as it is no longer categorized under anxiety disorders and a new cluster of symptoms was added: negative alterations in cognition and mood. In addition, the diagnostic threshold is lower for children, making the disorder developmentally sensitive. This study, however, uses the DSM-IV to determine the prevalence and severity of PTSD.

According to the DSM-IV, PTSD is categorized as the one of the few psychiatric diagnosis (along with acute stress disorder) that depends on a factor outside the individual, namely, a traumatic stressor. Hence, a patient cannot be given a diagnosis of PTSD unless he or she has been exposed to an event that is considered traumatic. The way the individual reacts to the incident is also important in the diagnosis. The dispositional attribution or how the person witnessing a certain incident processes and interprets the information and acts determines the level of severity of the psychological disorder or injury.

The conventional diagnosis of PTSD relies on measures of psychological, cognitive, and behavioral criteria using assessment tools such as structured and semi-structured interviews (e.g., Posttraumatic Symptom Scale-Interview Version (Foa et al., 1993), Structured Clinical Interview for DSM-IV-TR (First et al., 2002), administered diagnostic scales (Trauma History Questionnaire (Hooper, Stockton, Krupnick, \& Green, 2011)), Clinician-Administered PTSD Scale (Nader et al., 2012), Harvard Trauma Questionnaire (Mellica et al., 1992) and self-report questionnaires (Detailed Assessment of Posttraumatic Stress (Briere, 2001), PTSD Checklist (Ruggiero et al., 2003); Mississippi PTSD Scale (Lauterbach et al., 1997)).

There are six criteria in the DSM-IV that include situational and dispositional factors in the diagnosis of PTSD (refer to Table 1).

Table 1

Description of the Criteria in DSMIV for the Diagnosis of PTSD

\begin{tabular}{|l|l|}
\hline Criteria & Description \\
\hline A - Traumatic Stressor & $\begin{array}{l}\text { Patient exposed to catastrophic event involving actual or threatened death/injury, or threat to } \\
\text { physical integrity of self or others }\end{array}$ \\
\hline B - Intrusive Symptoms & $\begin{array}{l}\text { Flashbacks and/or traumatic daydreams/nightmares relieving the trauma. Caused by abnormal } \\
\text { processing of memory formation }\end{array}$ \\
\hline C - Avoidant Symptoms & $\begin{array}{l}\text { Reducing exposure to triggers of memories of the trauma. Feeling disconnected; psychic } \\
\text { numbing; avoidance of places, persons, or things associated with the trauma }\end{array}$ \\
\hline D - Hyper-arousal & $\begin{array}{l}\text { Nervous system is always on 'red alert' for return of danger. Hyper-vigilance; insomnia; difficulty } \\
\text { concentrating; general irritability; extreme startle response }\end{array}$ \\
\hline E - Duration of Symptoms & Persisting for at least one month \\
\hline F- Significance & $\begin{array}{l}\text { Suffers from significant social, interpersonal, or work related problems. Feeling disconnecting } \\
\text { from other people, society, spiritual sources of meaning }\end{array}$ \\
\hline
\end{tabular}

\section{Political Trauma and PTSD: Literature Review}

People who suffer from PTSD experience great difficulty in the aftermath of the traumatic event-which continues to affect their daily life long after the event has subsided. The significance of such symptoms and the prognosis has heightened in the last decade due to the scientific discoveries of neuropathological characteristics involved in PTSD (Pitman et al., 2012). A common reported finding of patients with PTSD is anatomical and 
structural changes in the size of the hippocampus, particularly a reduction in volume (Karl et al., 2006). The hippocampus is an important structure involved in memory formation, memory consolidation, and stress regulation (O'keege \& Nadel, 1978; Jacobson \& Sapolsky, 1991). A reduced size of the hippocampus, therefore, may suggest a dysfunction in the patient's ability to overcome the traumatic memory through extinction. As such, a person with PTSD has formed a strong learned association between the traumatic event and a threatening connotation, thereby making it difficult to pair the memory with a relaxed and calm state. An individual's memory and emotions may consequently be altered impairing some of their cognitive abilities.

Different studies have shown, however, that not all people who experience trauma develop PTSD. While $75 \%$ of adults have had a traumatic experience fulfilling current DSM-IV criteria as potential factors in the development of PTSD, only 12\% have actually developed PTSD (Breslau \& Kessler, 2001). The resilience most people have in the face of trauma can be explained by the conditioning of the neural mechanisms that allow a person to recover (Charney, 2004; Foa, 2000; Rothbaum \& Schwartz, 2002). No doubt, people learn to adapt to fear coming from a specific situation. However, when the threats and the incidents people witness or suffer from, vary in intensity and type, then the tolerance level diminishes and the adaptability level becomes less.

According to political psychologists, warfare occurs due to "cognitive biases and belief systems that limit our capacity for international trust and cooperation" (Brewer \& Miller, 1996, p. 137). Supporting the above statement, cognitive neuroscientists state that the flaw of memory and decision-making lies not only in human passion, but also in cognitive machinery (Tversky \& Kahneman, 1974). Cognitive machinery is based on the neural interconnections between areas of the brain that are actively prominent during cognition (the prefrontal cortex) and emotional arousal (the limbic system) (Leon Hoffman M.D. in Beyond Freud, Oct. 2011). Literature in psychological research supports that there are explicit memory biases for threat-relevant information in panic disorders and PTSD, but not in generalized anxiety disorder (GAD) (Coles \& Heimber, 2002). Therefore, individuals with PTSD suffering from unwanted memories through flashbacks, nightmares, and intrusive recollections of their traumatic event tend to experience explicit memory biases and thereby endorse irrational beliefs (Kindt \& Engelhard, 2005).

\section{The Attribution Theory and PTSD}

Most theorists are concerned with the way people are driven by their emotional and motivational needs to explain an encountered incident and how they direct their blame. To understand human propensity to conflicts and use of violence, cognitive psychologists emphasize the significance of perceptions and misperceptions in (1) political decision-making at times of crisis (Stoessinger, 2010; Jervis, 1976); (2) how people account for events they witness; and (3) why people commit such actions (Antaki \& Brewen, 1982). In line with this, Fritz Heider's attribution theory describes how people explain (make attributions about) their behavior and the behavior of others. According to the theory, behavior can either be attributed to a disposition or situational factors (Jones \& Nisbett, 1972; Weiner, 1974; Weiner, 1986). The significance of a situation, how the individuals impacted by the trauma attribute and interpret events, and how this relates to their thinking and behavior brings our attention to the attribution theory.

In Lebanon, a study showed that the impact of trauma represented in PTSD is shaped and structured by group memberships, sectarian, religious, gender and socioeconomic groups. Haslam and Reicher theorized a relationship between identity and stress (Haslam \& Reicher, 2006). They argued for an explicit acknowledgement of social and group dimensions to the experience of stress. By placing social identities at the 
center of the stress process, it becomes apparent that these group memberships structure the nature and extent of traumatic events encountered.

Moreover, victims of war make attributions to defend what they perceive as attacks and pointing to injustice in an unfair world. Even perpetrators of violence tend to blame the victims for their plight as demonstrated by Lerner (1980) in the "just world phenomenon". This is emphasized in various studies whereby participants and bystanders tend to blame mass violence on the victims or when professional soldiers blame the leaders for their acts of violence against others (Waller, 2007). Perpetrators of violence that committed massacres during the Lebanese Civil War expressed their dissociation from society and loss of affection and empathy with others. They additionally blamed their leaders for putting them in situations - the fear of the other and the existential threat (kill or be killed) — where they could not but kill the other (Kriedie \& Monroe, 2002).

In another study comparing dispositional and situational attribution in PTSD, researchers proposed that attributions for important events with outcomes perceived as highly negative may be more significant in influencing a person's response. On the other hand, attributions to less important events with less negative outcomes may be less significant in influencing a person's response (Abramson et al., 1989).

People with PTSD tend to blame the situation for their injury, which makes them more prone to anger and revenge consequently developing conflictive norms. The question then becomes how would continuous exposure to trauma in the form of violence, persecution, discrimination; fear of the other, captivity and displacement affect the disposition of the people. In his study of the Israeli-Palestinian conflict, Daniel Bar Tal, focused on the impact of durable and continuous trauma in developing the conflictive ethos:

Under prolonged conditions of intractable conflict, when violent experiences are common collective experiences, the conflict comes to preoccupy most members of the society. They therefore develop an "ethos of conflict", which provides a clear picture of the conflict, its goals, its conditions, requirements and images of one's own group and of the rival. (Bar-Tal, 1998; 2000, p. 353)

Although not all people are predisposed to acquire PTSD, those who acquire it add to the severity and intractability of the conflict. In this case, conflictive ethos is not only societal but is also neuropsychological. It is, therefore, challenging to treat and add to the intractability of the situation, unless drastic steps are taken.

A key feature of PTSD is the aspect of captivity. Captivity symbolizes an event where the individual experiencing trauma is unable to escape the situation. Psychological captivity is even more intensified when individuals are displaced and forced to leave their home, finding themselves trapped living in camps at the mercy of the other. Even though governmental and non-governmental organizations (NGOs) try to help the displaced, the refugees still feel that their everyday life and future is not in their hand. In addition to the war-related stressor events they have been exposed to, the displaced war-survivors are believed to experience enduring contextual stressors - including socioeconomic disadvantage and poverty, changes in family structure and functioning, loss of social support, lack of access to education, overcrowded housing, hostility and racism, acculturation difficulties, marginalization and isolation, and finally cultural bereavement.

The purpose of the study is first to fill the research gap by shedding light on the prevalence of PTSD among "civilians" living in "ongoing wars" and trauma to include "displacement", and two to point to the social and political behavioral implications of PTSD. To connect the dots, we knit together the neuro-psychological symptoms of PTSD to underscore the impact of emotions and memory on the cognitive abilities; we look at the role of perceptions and misperceptions in shaping people with PTSD decisions' to go to war, and we correlate 
how affected people fall into the fundamental attribution errors to justify their acts of violence or to blame for their own victimization. Taking all the psychological symptoms into consideration, PTSD an individual neuropsychiatric syndrome could have collective impact on societies with ongoing wars rendering conflict resolution and reconciliation more difficult.

While a handful of research is conducted on the impact of violence and conflict-related traumas on civilians in Lebanon, a country that undergoes repeated traumas and is the refuge to many displaced people (i.e., Palestinians and Syrians), most of the studies were conducted on children. This case study will include Syrian refugees living in Lebanon. It will assess the prevalence and impact of PTSD among the Syrian refugees in Lebanon. In addition, we hypothesize that people with PTSD are more prone to be conflictive. We hope that the findings could present the interested governments and international, regional and local NGOS with facts necessary for conflict management, policy-making, and humanitarian aid planning.

\section{Case Study of a People Living with Continuous, Aggravated PTSD and Displacement: Syrian Refugees in Lebanon}

Due to the ongoing war in Syria, many were forced to flee their homes and seek shelter in Lebanon, where they currently face harsh living conditions as of May 2015, according to the United Nations High Commission of Refugees (UNHCR), there are more than 1.2 million registered Syrian refugees - children and adults - in Lebanon, a country of 4 million (UNHCR Syria Regional Refugee Response, 2015). The statistics indicate that nearly half of the refugees are younger than 17. Most of the Syrian refugees in Lebanon live among poor communities or in informal tented settlements (ITS), mainly in the Bekaa and North. Pressure on the Lebanese water, energy, transportation, communication and infrastructure—already suffering and ill managed—plus the poor job competition create ongoing tension between the Lebanese and Syrians. The massive influx of refugees in Lebanon is detrimental to both the Lebanese and Syrians. The insufficient financial support to deal with the influx, as well as a series of governmental measures to restrict the move of Syrians into Lebanon and their ability to work, have worsened the human security of Lebanese and Syrians.

Since most of the crime and security incidents are taking place in the Bekaa and North, the Syrians refugees are blamed and consequently the camps are regarded as safe havens for terrorists (Khatib, 2014). These incidents, therefore, have shifted the perception of the Syrian refugees in Lebanon from victims to perpetrators, if not terrorists. The shift in perception coupled with economic marginalization may have pushed more refugees down the path of crime and terrorist acts. This, in turn, has unjustly ruined their image and undermined their relation with the Lebanese population. Such generalizations, discrimination, and prejudice against the Syrians have impacted them economically, socially, politically, and psychologically.

The current Syrian situation is the propulsion caused by an accumulation of trauma-inducing incidents that have shaped the Syrian social psychology. To better understand the impact of such traumas it is imperative to review the politics, culture, and history of Syrian people.

\section{Trauma of Colonization: Search for Identity}

A wealth of literature investigating conflicts and violence in the Middle East blame colonization for setting the basis of ethnic and religious divisions among people, for the legitimization of authoritarian regimes, and the East-West - or what is mostly claimed Islam-West-dichotomy under the banner of clash of civilizations. 
Torn between defining their new post-Ottoman identity and establishing strong governing institutions and ruling governments, Syria, like most Arab states, has been witnessing different external and internal traumatic events. The identities of those traumas were diverse, and the perceived "enemy" changed throughout the years.

In the first decade of the 20th century, Greater Syria witnessed strong Arab nationalist clashes against the then Ottoman Empire, who lost WWI against the Europeans. Demarcated by a European agreement, Syria's boarders were artificially drawn, giving parts of it to establish what is today Lebanon and reducing the Islamic and Arab identity to a Syrian national identity. The epitome that defined the geopolitics of Syria and its people's identity crisis was the creation of the state of Israel whose expansionist policy set the stage for ongoing conflicts in the region. Being at the front line with Israel, Syria's domestic and foreign politics and the populations' attitudes and norms have been heavily impacted.

\section{Hyper Security and Authoritarianism Trauma}

Three decades of military coup d'états ended with the reign of a socialist secular authoritarian Baath Regime led by Hafez Al Assad. Fear and insecurities of the Israeli growing power, humiliation due to 1948 occupation of Palestine commemorated by the Arabs as the Catastrophe (Nakba), the loss of 1967 war and the loss of the Golan Heights, anger and aversion because of the Israeli occupation, and oppression of the Palestinian people have all been major markers of the Syrians' sense of who they are. The era of stability, economic austerity, and sense of Syrian pride muffled the sense of opposition to a regime that survived many regional challenges - such as 1976 Camp David agreement, the involvement in the Lebanese Civil War 1975-1989, and 1982 Muslim brotherhood uprising, which was silenced by the regime killing more than 20,000 people in the city of Hama (Fisk, 2010). Until this present day, the Hama massacre is still alive in the memory of many Syrians, and therefore the trauma is still lingering. The revenge and anger that they hold after the massacres still play a huge role in the present Syrian violence.

Bashar Al Assad the son, who took over after the death of Bashar, who reckoned the need for reform in Syria, adopted certain economic liberalization policies, however failed to parallel it with political liberalization. The outcome of the economic liberalization was the accumulation of wealth in the hands of his inner circle and the large business class that resulted in widening the gap between Urban and rural societies, and disenfranchising the majority Sunni, hence creating a sense of discontent (Haddad, 2005). All forms of discontent were suppressed by either cooption or by further suppression, a policy that led to the 2011 rise of the people against the regime.

\section{Trauma of the On-going Civil War}

For the past four years, Syria has been witnessing a civil war considered the 21 st century's worst crisis (The Guardian, 2013). War-torn Syria is now suffering from destroyed infrastructure, hospitals and schools, and an enormous wave of internal and external displacement. The destruction was not only material, but also severely damaged the minds and souls of people. It may take years to be rebuilt, but several generations to restore the damaged souls and social relations of the Syrian people. The current war portrays the anger and revenge that have accumulated throughout long years of oppression. The crisis is not only between opposing Syrian parties, as new players have entered the arena.

Due to several reasons that are beyond the scope of the paper, extremism has enormously spread among Syrian and foreign fighters who came to Syria for what they believe is "jihad". Syria is now a haven for jihadist extremist fighters from all over the globe. These fighters are traumatizing Syrian people as they are seen as 
"external invaders". Although many Syrians may be members of these extremist groups, namely Islamic State of Iraq and Sham (ISIS), the Syrian extremists do not treat other Syrians as fellow citizens.

\section{Trauma of Displacement}

Nearly 20 million Syrians are suffering in what the UNHCR, António Guterres has described as "the worst humanitarian disaster since the end of the Cold War" (Chulov, 2013). The lack of sufficient humanitarian aid and support from the international community has worsened the Syrian crisis's humanitarian situation. More than half of the Syrian people have now become internally displaced people (IDP) and refugees. According to the latest numbers of UNHCR, there are a total of 4.3 million refugees, with nearly $51 \%$ under the age of 18 (UNHCR, 2015). The UN Office of Coordination of Humanitarian Affairs (OCHA) found that the total number of IDPs is 7.6 million.

In Lebanon alone, there are 1,078,338 million refugees dispersed from the North to the South of the country. In addition to the previous war and oppression traumas the Syrian refugees are carrying with them, they are now faced with a new type of trauma, "the trauma of displacement". A survey of 1,100 Syrian youth in 2014 found that $41 \%$ of Syrians between the ages of 15 and 24 in Lebanon have contemplated suicide (Save the Children). The figure is more than $50 \%$ for females in the same age group. Psychologists and doctors working with Syrian children reported symptoms of phobia, hysteria, night terrors, and regression in development through bed-wetting. According to Anthony MacDonald, the chief of child protection at UNICEF in Lebanon, one "can safely assume that the majority of the population coming from Syria has some form of distress" (Shaheen, 2004). He emphasized that children and adolescents experience a "re-trauma" when they arrive in Lebanon as a result of poverty, living conditions, bouts of violence, and a lack of schooling that adds to tensions at home. In line with the above statement, BassemAl Faris, a Syrian doctor currently working in the Bekaa, clearly stated, "(the situation is) destroying a people beyond the destruction caused by chemical weapons". Unfortunately, the Syrian crisis and the obliteration of humanity continue.

\section{Data and Methodology}

Lebanon, a country characterized by continuous political conflicts and ongoing wars, is used as a case study. The study targeted Syrian refugees in different areas of Lebanon: Beirut, North Lebanon, and the Bekaa. The selected refugees were settled in temporary and informal tented settlements. ${ }^{1}$ Information International ${ }^{2}$, an independent non-political consultants group located in Beirut, conducted the interviews.

The survey questionnaire consists of four main sections: (1) anonymous biographical background; (2) social and political attitudes; (3) DSM-IV diagnostic criteria; and (4) acustomized UCLA PTSD index set of questions about the exposure to violence and the social and psychological impact (Rodriguez, Steinberg, \& Pynoos, 1999).

The questions were customized to fit the context of the sample. The survey was administered by an independent research center, Information International. Before administering the survey, it was tested for validity and reliability. The field supervisors reviewed each questionnaire on the day of submission and

\footnotetext{
${ }^{1}$ As of the beginning of the Syrian conflict, Lebanon ruled out erecting refugee camps as done in Turkey, Jordan and Iraq for political reasons. Instead, other options have been considered by the Lebanese government including using abandoned buildings as collective shelters, paying Lebanese families who are hosting Syrian refugees, and covering the rent of some of the poorest refugee families.

${ }^{2}$ Information International is a regional research and consultancy firm located in Beirut, for more check: http://www.information-international.com/index.php/about-us/profile
} 
corrective measures were taken when necessary. Once the supervisors cleared the questionnaires, they were dispatched to the main office on a daily basis. The supervisors and assistant analyst edited each completed survey to check for clarity, understanding, and completeness. Once the supervisors cleared them, the questionnaires were dispatched to the coding department. They were coded according to the Consortium. A neurologist ${ }^{3}$ - core investigator who participated in setting the diagnosis criteria-educated and trained the Information International survey team.

A total of 12 field workers administered the survey. The fieldwork started on April 1, 2014 and ended on May 27, 2014. A sum of 496 Syrian refugees was approached to fill the survey. Respondents were 21 years of age, or older. Based on the latest statistics about Syrian Refugees released by UNHCR; we adopted a proportionate population sample to distribute the relevant questionnaires. Participants were randomly selected and if they accepted to participate, the objectives of the survey were explained and they were given informed consent.

\section{Sample Description}

A total of 450 Syrian refugees completed questionnaires to study the prevalence and social and political impact of PTSD in Lebanon. The sample consisted of 50.9\% males and $49.1 \%$ females. The majority of the participants were between 21 and 29 years old as noted in (see Table 2).

Table 2

Distribution of Respondents by Age Groups

\begin{tabular}{lcc}
\hline Age Groups & Frequency & Percentage (\%) \\
\hline $21-29$ & 165 & 36.7 \\
$30-39$ & 128 & 28.4 \\
$40-49$ & 94 & 20.9 \\
$50-59$ & 34 & 7.6 \\
$60-64$ & 29 & 6.4 \\
Total & 450 & 100.0 \\
\hline
\end{tabular}

A larger number of questionnaires (236) were distributed in the Bekaa area (see Table 3). It is important to mention that most of the tension and violence between Syrians and Lebanese take place in this area. Most noted incident was the kidnapping and killing of Lebanese soldiers and security forces in 2014.

Table 3

Distribution of Questionnaires per Area

\begin{tabular}{lcc}
\hline Area & Number of Questionnaires & Percent of questionnaires (\%) \\
\hline Beirut & 20 & 4.4 \\
North & 194 & 43.1 \\
Bekaa & 236 & 52.4 \\
Total & 450 & 100.0 \\
\hline
\end{tabular}

In addition, most respondents, $62.4 \%$, completed an elementary/intermediate level of education (see Table 4).

\footnotetext{
${ }^{3}$ A Diplomat of the American board of Psychiatry and Neurology who during his practice in California, United States, he treated troops who came back from Iraq and Afghanistan with PTSD, and is interested in the neurological and organic - in addition to the psychiatric-markers of PTSD.
} 
Table 4

Distribution of Respondents by Education Level

\begin{tabular}{lcc}
\hline Highest Educational Level Achieved & Frequency & Percentage $(\%)$ \\
\hline Illiterate & 39 & 15.3 \\
Elementary/Intermediate & 281 & 62.4 \\
Secondary & 54 & 12 \\
B.A/B.S & 31 & 6.9 \\
Vocational/Technical & 12 & 2.7 \\
DK/NA & 3 & 0.7 \\
Total & 450 & 100.0 \\
\hline
\end{tabular}

Table 5 indicates that more than half, $58 \%$, of the respondents do not earn a monthly income.

Table 5

Distribution of the Respondents by Personal Monthly Income

\begin{tabular}{lcc}
\hline Personal Monthly Income (in dollars) & Frequency & Percentage (\%) \\
\hline$<450$ & 154 & 34.2 \\
$450-750$ & 31 & 6.9 \\
$751-1000$ & 4 & 0.9 \\
No income & 261 & 58 \\
Total & 450 & 100.0 \\
\hline
\end{tabular}

\section{Results}

496 participants were recruited to participate in the study. 450 responded to the questionnaires. 46 participants refused to participate due to "survey fatigue" and lack of time. Respondents who met all DSM IV criteria were diagnosed with full PTSD, and those who met criteria A and any of criteria B, C, or D were diagnosed with partial PTSD. 277 (61.56\%) of the Syrian refugees met the criteria of full PTSD. 134 (29.78\%) refugees did not report any symptoms of PTSD, while 39 (8.67\%) participants fit the criteria of partial PTSD (see Table 6).

Table 6

Diagnosis in Percent of PTSD among Syrian Refugees

\begin{tabular}{llccc}
\hline & & Frequency & Percent (\%) & Valid Percent (\%) \\
\hline \multirow{4}{*}{ Valid } & No PTSD & 134.00 & 29.78 & 29.78 \\
& Partial PTSD & 39.00 & 8.67 & 8.67 \\
& Full PTSD & 277.00 & 61.56 & 61.56 \\
& Total & 450.00 & 100.00 & 100.00 \\
\hline
\end{tabular}

The prevalence of trauma among the Syrian refugees was based on two questions in the survey: (1) have you ever been the victim of any act of violence, and or bullying? and (2) does this incident still affect you activities of daily living? (see Tables 7-10). The descriptive statistics indicated that $24 \%$ of the participants had been the victims of any act of violence, while $76 \%$ had not. Same for bulling $38 \%$ suffered from bullying with 51.8 not too long ago (see Table 8). Since the images of the on-going violence are redundant on the media, we asked the subjects how images of such violence impact them, $63 \%$ reported that they get very distressed (see Table 9). To confirm the severity of PTSD, out of the participants who had experienced an act of violence, $41.67 \%$ claimed that the incident still affects their daily activities, while $58.33 \%$ claimed that it does not (see Table 10). 
Table 7

Assessing the Prevalence of PTSD in Syrian Refugees Based on the Question "Have You Ever Been the Victim of any Act of Violence?"

\begin{tabular}{cllcc}
\hline & & Frequency & Percent (\%) & Valid Percent (\%) \\
\hline \multirow{3}{*}{ Valid } & Yes & 108.00 & 24.00 & 24.00 \\
& No & 342.00 & 76.00 & 76.00 \\
& Total & 450.00 & 100.00 & 100.00 \\
\hline
\end{tabular}

Table 8

Findings of Variables of High Conflict Associated with PTSD

\begin{tabular}{|c|c|c|}
\hline Variables & Questions & Findings \\
\hline \multirow{15}{*}{ Bullying } & \multirow{2}{*}{ Have you ever suffered from bullying? } & $60.2 \%$-Never \\
\hline & & $38 \%$ - Suffered \\
\hline & \multirow{3}{*}{ If yes, when? } & $36.7 \%$-Not too long ago \\
\hline & & $25.1 \%$ - Recently \\
\hline & & $18.1 \%$ - Long time ago \\
\hline & \multirow{2}{*}{ If so, are you still in contact with those people? } & $28.1 \%-$ Yes \\
\hline & & $71.9 \%-\mathrm{No}$ \\
\hline & \multirow{4}{*}{ If yes, do you talk about how you feel with them? } & $37.5 \%-$ No \\
\hline & & $27.1 \%$ - Always \\
\hline & & $22.9 \%$ - Sometimes \\
\hline & & $12.5 \%$-Rarely \\
\hline & \multirow{4}{*}{ When verbally attacked, it is normal to? } & $44 \%$ - Ignore the situation \\
\hline & & $26.7 \%$ - Wait, relax and solve problem \\
\hline & & $19.8 \%$ - Immediately react \\
\hline & & $9.6 \%$ - Wait, think, then retaliate \\
\hline
\end{tabular}

Table 9

Findings of Variables of high conflict Associated with PTSD

\begin{tabular}{|l|l|l|}
\hline Variables & Questions & Findings \\
\hline \multirow{3}{*}{$\begin{array}{l}\text { Impact of } \\
\text { Media }\end{array}$} & $\begin{array}{l}\text { How do you feel when you see violence } \\
\text { displayed on media? }\end{array}$ & $63.1 \%$-Very distressed \\
\cline { 2 - 3 } & Which type of violence? & $20.4 \%$ - Slightly upset \\
\cline { 2 - 3 } & $10.9 \%$ - Don't really care \\
\cline { 2 - 3 } & $88.9 \%$ - Don't know \\
\hline
\end{tabular}

Table 10

Impact of Trauma on Daily Activities

\begin{tabular}{lccc}
\hline \multicolumn{2}{l}{ Does this incident still affect your activities of daily living? } & Frequency & Percent (\%) \\
\hline \multirow{2}{*}{ Valid } & Yes & 45 & 41.67 \\
& No & 63 & 58.33 \\
\multirow{2}{*}{ Missing } & Total & 108 & 100 \\
& Not applicable & 342 & 100 \\
\hline
\end{tabular}

The results indicated that there was an equal probability for males and females to have partial PTSD and full PTSD diagnosis. There were no significant differences in educational background across the levels of PTSD diagnosis. Also, unemployed and employed participants were equally probable to have partial PTSD or 
full PTSD. Participants with no PTSD, however, had higher monthly income than participants who were diagnosed with full PTSD.

The survey assessed other variables and their association with PTSD, including anger, aggressiveness and anger, violence, forgiveness, and revenge (refer to Tables 11-14). Data confirm that Low impulse control paralleled with unmanaged emotions, extreme behavior and tendency to blame the others, lead to dysfunctional behavior increasing conflictive or "high conflict people" (Eddy, 2012).

Table 11

Findings of Variables of High Conflict Associated with PTSD

\begin{tabular}{|c|c|c|}
\hline Variable & Questions & Findings \\
\hline \multirow{13}{*}{ Anger } & \multirow{2}{*}{ I regret when I act with anger: } & $81.6 \%$ - Regret \\
\hline & & $18.4 \%$ - Do not regret \\
\hline & \multirow{4}{*}{ When someone insults you, you get very angry and get back: } & $34.4 \%$ - Get angry and sometimes get back \\
\hline & & $28.7 \%$ - Never get angry \\
\hline & & $21.8 \%$ - Rarely get angry \\
\hline & & $15.1 \%$ - Always get angry \\
\hline & \multirow{3}{*}{ I really get angry when: } & $34.9 \%$ - Interrupted while talking \\
\hline & & $27.8 \%$ - Cut off while driving \\
\hline & & $13.3 \%$ - Advice not taken seriously \\
\hline & \multirow{4}{*}{ If someone angers/hurts you: } & $42 \%$ - Sometimes forgives \\
\hline & & $16.7 \%$ - Always forgives \\
\hline & & $14.9 \%$ - Rarely forgives \\
\hline & & $26.4 \%$ - Never forgives \\
\hline \multirow{4}{*}{$\begin{array}{l}\text { Aggressiveness } \\
\text { \& Violence }\end{array}$} & \multirow{2}{*}{$\begin{array}{l}\text { After the encountered incident, did you feel a sense of } \\
\text { rebellion? }\end{array}$} & $52.8 \%-$ Yes \\
\hline & & $47.2 \%-\mathrm{No}$ \\
\hline & \multirow{2}{*}{ I sometimes have sudden feelings I can't hold back: } & $69.8 \%-$ Yes \\
\hline & & $29.8 \%-$ No \\
\hline \multirow{4}{*}{ Forgiveness } & \multirow{4}{*}{ If someone angers/hurts you: } & $42 \%$ - Sometimes forgives \\
\hline & & $16.7 \%$ - Always forgives \\
\hline & & $14.9 \%$ - Rarely forgives \\
\hline & & $26.4 \%-$ Never forgives \\
\hline Revenge & “An eye for an eye" & No significant differences between PTSD groups \\
\hline
\end{tabular}

Table 12

Findings of Variables of High Conflict Associated with PTSD

\begin{tabular}{|l|l|l|}
\hline Variables & Questions & Findings \\
\hline $\begin{array}{l}\text { Perception of } \\
\text { Injustice }\end{array}$ & $\begin{array}{l}\text { Do you think that the Syrian government protects the rights } \\
\text { of minorities? }\end{array}$ & No significant differences between PTSD groups \\
\cline { 2 - 3 } & Does social injustice exist in Syria? & No significant differences between PTSD groups \\
\hline $\begin{array}{l}\text { Basis of } \\
\text { Injustice in } \\
\text { Syria }\end{array}$ & $\begin{array}{l}\text { Based on the question above: If yes, what is the basis of } \\
\text { injustice in Syria? }\end{array}$ & $29.39 \%$ - Political affiliation \\
\cline { 2 - 3 } $\begin{array}{l}\text { Sectarian } \\
\text { Discrimination }\end{array}$ & Do you feel that there is sectarian discrimination in Syria? & $\begin{array}{l}\text { No significant differences between PTSD groups } \\
\text { Yes 79.2\% of those w/PTSD }\end{array}$ \\
\cline { 2 - 3 }
\end{tabular}


Table 13

Findings of Variables of High Conflict Associated with PTSD

\begin{tabular}{|c|c|c|}
\hline Variables & Questions & Findings \\
\hline $\begin{array}{l}\text { Political } \\
\text { Dissatisfaction }\end{array}$ & I am satisfied with the current political situation: & No significant differences between PTSD groups \\
\hline \multirow{6}{*}{$\begin{array}{l}\text { Political } \\
\text { Allegiance }\end{array}$} & \multirow{2}{*}{ Do you belong to a political party? } & $98.9 \%-$ No \\
\hline & & $1.1 \%-\mathrm{Yes}$ \\
\hline & \multirow{2}{*}{ If no, do you sympathize with a political party? } & $83.4 \%$ - Don't sympathize \\
\hline & & $14.8 \%$ - Sympathize \\
\hline & \multirow{2}{*}{ If yes, specify: } & $45.5 \%$ - Free Syrian Army \\
\hline & & $43.9 \%$ - Syrian Opposition \\
\hline \multirow{4}{*}{$\begin{array}{l}\text { Political } \\
\text { Participation }\end{array}$} & \multirow{4}{*}{$\begin{array}{l}\text { You would participate in a protest if it is targeting: (a) } \\
\text { political issues; (b) social issues; (c) environmental issues; } \\
\text { and (d) economic issues: }\end{array}$} & $13.6 \%$ - Political issues \\
\hline & & $32.7 \%$ - Social issues \\
\hline & & $30.9 \%$ - Environmental issues \\
\hline & & $29.1 \%$ - Economic issues \\
\hline $\begin{array}{l}\text { Compliance to } \\
\text { Authority }\end{array}$ & $\begin{array}{l}\text { It is respectful to listen to your parents even though they } \\
\text { might hurt you. } \\
\text { It is rational to ignore you boss's abusive behavior when } \\
\text { you need the job. }\end{array}$ & No significant differences between PTSD groups \\
\hline
\end{tabular}

Table 14

Findings of Variables of High Conflict Associated with PTSD

\begin{tabular}{|c|c|c|}
\hline Variables & Questions & Findings \\
\hline \multirow{5}{*}{$\begin{array}{l}\text { Perception of } \\
\text { Terrorism }\end{array}$} & \multirow{5}{*}{ A suicide bombing on an Israeli civilian bus is considered: } & $42 \%$ - Completely unacceptable \\
\hline & & $35.1 \%$ - Unacceptable \\
\hline & & $7.6 \%-$ Neutral \\
\hline & & $7.6 \%$ - Completely acceptable \\
\hline & & $7.8 \%$ - Acceptable \\
\hline \multirow{4}{*}{ Religiosity } & \multirow{4}{*}{ How did you find yourself religiously speaking? } & $42.6 \%$ - More religious \\
\hline & & $36.1 \%$ - Didn't change \\
\hline & & $3.7 \%-$ Loss of faith \\
\hline & & $17.6 \%$ - Confused \\
\hline
\end{tabular}

\section{Discussion and Implications}

Although PTSD is an individual pathology, in countries with on-going conflicts and different forms of trauma, PTSD tends to have a cumulative effect on individuals with PTSD tend to be more conflictive than people with no PTSD. The majority of the Syrian refugees who fled the war and settled in Lebanon under distressed situation suffer from PTSD. $61 \%$ of the Syrian refugees met all every criteria in the DSM-IV. In line with this, $24 \%$ were the victims of direct violence, $38 \%$ suffered from bullying, and the rest witnessed violence and other traumatizing events. Only $9 \%$ met criteria A, and one of B, C, or D criteria.

Although a large sum of participants showed high level of compliance with authority, respondents affiliated with the opposition, expressed dissatisfaction with the political, social, and economic situation. Moreover, the majority of those diagnosed with PTSD tend to have a propensity to be conflictive. A total of $49 \%$ get angry when insulted, $34.9 \%$ get angry when interrupted, and $27.8 \%$ get angry when cut off while driving. While $81 \%$ of the $20 \%$ who immediately react with anger regret their reaction, most agreed with the statement "an eye for an eye" with only $16.7 \%$ forgiving others. As criterion D stipulates, people with PTSD 
are on high alert as $82 \%$ of the injured have sudden feelings that they can't hold back. As stipulated in criterion $\mathrm{C}$, the tendency to reduce exposure to triggers of memories, or any place or incident that is associated with trauma is represented in the responses with $68 \%$ of those with full PTSD denied responding to whether they had a sense of rebellion. In addition, $68 \%$ of those with full PTSD denied responding to whether they had a sense of rebellion. Also 44\% of those with PTSD reported that they ignore when they're verbally attacked. Low impulse control, dissociation from the situation and avoidance of contact with or communication with the "other"; render conflict resolution more difficult. In addition, contrary to participants who were diagnosed with no PTSD, more of those with full PTSD believed in "an eye for an eye" approach to dealing with enemies, and that acts of violence are justifiable. We conclude and agree that victims of PTSD struggling with fear and anger greatly interferes with their abilities to concentrate, listen carefully, and make cooperative decisions-so problems often go unresolved for a long time.

\section{Limitations}

In the case of a known trauma of recent occurrence - most often a civilian disaster or war - the diagnosis of PTSD is relatively straightforward, based on the criteria listed above. DSM-IV introduced a new diagnostic category, acute stress disorder, to differentiate between time-limited and longer-term stress reactions. In acute stress disorder, the hyper-arousal and intrusive symptoms last between two days and four weeks. If the symptoms last beyond four weeks, and all of the above criteria are met, the diagnosis is changed to PTSD.

Although PTSD was found to have a high inter-rater reliability and test-retest reliability (Narrow et al., 2012), measures of PTSD severity through clinician-administered interviews, scales, and self-report questionnaires are subject to inaccuracy. Clinicians' personal judgment of the patient's historical report and the patient's exaggeration or diminution of the severity of his or her symptoms renders such diagnostic tools subjective by nature. Patients with PTSD avoid the recollection of distressing memories of the traumatic event and, thus, may fail to provide clinicians with indicators for the appropriate diagnosis. They may also not establish the link between their present symptoms and the causal traumatic event and, consequently the symptoms may be masked by other conditions such as anxiety, depression, and substance use (McPherson, 2003). Such tools for PTSD evaluation were, up till recently, the only means to determine symptoms pertaining to PTSD.

The diagnosis of PTSD is more difficult in cases of delayed reaction to trauma. Some individuals do not develop symptoms of PTSD until months or even years after the traumatic event. DSM-IV-TR specifies an interval of at least six months between the event and the development of symptoms for a diagnosis of PTSD with delayed onset. Delayed symptoms are often triggered by a situation that resembles the original trauma, as when a person raped in childhood experiences workplace sexual harassment.

The Syrian crisis is ongoing, and the high numbers of those diagnosed with PTSD might drop after the war is over. Based on the above limitations, we suggest follow-up studies with more clinical diagnostic tests administered on the selective sample of those found with PTSD. To encounter the limitation we are conducting qualitative analysis to unravel the human face of the trauma and to better explain their behavior, in order to devise better peace building policy recommendations.

\section{Conclusion and Recommendations}

The study attempted to fill in the gap in the literature on PTSD, by examining the prevalence and impact 
of PTSD in countries with ongoing conflicts and violence, in this case Syrian refugees in what has become an ongoing Middle Eastern political trauma. The results clearly indicated the high prevalence of PTSD among Syrian refugees that have faced war, displacement, and captivity, and the collective impact of people suffering with PTSD on the intractability of conflicts. Such high rates of PTSD call for immediate attention in the prevention of the escalation of violence, and for quick response and effective handling of the people impacted by trauma. Criterion E in DSM-IV indicates that "time" is an important in determining the severity of PTSD; hence timely response to crisis is essential in mitigating the impact of trauma and reducing injury to the emotion and memory of human beings.

DSM-IV Criterion A stresses the importance of the situation through direct exposure to a catastrophic event involving actual or threatened death/injury, or threat to physical integrity of self or others. As such, urgent action should be taken to move the victims to a different location, while on a larger scale this could be in cleaning up the impact of destruction, conduct collective and individual counseling, and provide victims with physical, spiritual and moral support. This situational attribution among PTSD patients could also be directed towards the actions of those victims see as "the other". At this point, joint efforts to mediate between the different groups should be increased and lines of communication between the warring groups is necessary to dilute ethnic differences and promote reconciliation.

Management of the collective phenomenon of PTSD is multidisciplinary, and requires the institutionalization of international as well as national program to tackle PTSD in societies that suffer from continuous conflicts. Such program involves medical personnel, psychologists, social workers, and governmental and non-governmental organizations. Within the medical scope, the DSM criteria and other diagnostic tests are used to confirm the injury, and accordingly a treatment plan is devised. The treatment plan includes neurologists, psychiatrists, psychologists and social workers. It is beyond the scope of this paper to detail the medical plan.

The social and political impact of PTSD demands the cooperation and coordination of efforts of governmental institutions and non-governmental organizations to mitigate the impact of the trauma. Successful programs devised to treat veterans with PTSD could also be adopted to manage civilians. Some of the steps required for successful personal and social communication and reconciliation include (National center for PTSD-US VA dept.): (1) creating social support network to cope with PTSD while maintaining or rebuilding family and friend relationships with dedication, perseverance, hard work, and commitment; (2) sharing feelings honestly and openly with an attitude of respect and compassion; and (3) continual practice to strengthen cooperative problem solving and communication.

It is also important to underscore the positive aspect of resilience- that is when civilians live in societies with ongoing conflicts but do not develop PTSD, or those with PTSD who are able to overcome the negative impact of PTSD through change in lifestyle, but more so adapt and succeed. Recognition of the suffering and/or heroism of those witnessing continuous trauma might also be a factor in mitigating the impact of trauma and shifting the paradigm from loss to gain. However, this requires further studies that assess how a shift of paradigm would change the suffering to an opportunity.

In a nutshell, Post conflict reconstruction plans can build the physical infrastructure, but it is arduous to remake the human being. In order to prevent further victimization, and to contain the impact of violence and trauma, focus on the human being's ability to cope, and adapt during difficult times is the most pertinent for establishing peace. 


\section{References}

Abdeen, Z., Qasrawi, R., Nabil, S., \& Shaheen, M. (2008). Psychological reactions to Israeli occupation: Findings from the national study of school based screening in Palestine. International Journal of Behavioral Development, 32(4), 290.

Abramson, L., Alloy, L., \& Metalsky, G. (1989). Hopelessness depression: An empirical search for a theory-based subtype. Contemporary Psychological Approaches to Depression, 96(2), 358-372.

Al-Jawadi, A. A., \& Abdul-Rhman, S. (2007). Prevalence of childhood and early adolescence mental disorders among children attending primary health care centers in Mosul, Iraq: A cross-sectional study. BMC Public Health, 7, 274.

Alyahri, A., \& Goodman, R. (2008). The prevalence of DSM-IV psychiatric disorders among 7- to 10-year-old Yemeni schoolchildren. Social Psychiatry and Psychiatric Epidemiology, 43, 224-230.

Antaki, C., \& Brewin, C. R. (Eds.) (1982). Attribution and psychological change: Applications of attributional theories to clinical and educational practice. London Academic Press.

Barber, B. K. (2008). Contrasting portraits of war: Youths' varied experiences with political violence in Bosnia and Palestine. International Journal of Behavioral Development, 32, 298-309.

Bar-Tal, D. (2007). Sociopsychological foundations of intractable conflicts. American Behavioral Scientist, 50, 1430-1453.

Bleich, A., Gelkopf, M., \& Solomon, Z. (2003). Exposure to terrorism, stress-related mental health symptoms, and coping behaviors among a nationally representative sample in Israel. JAMA, 290(5), 612-620.

Bleich, A., Gelkopf, M., Melamed, Y., \& Solomon, Z. (2006). Mental health and resiliency following 44 months of terrorism: A survey of an Israeli national representative sample. BMC, 4, 21.

Briere, J. (2001). Detailed assessment of post traumatic stress. DAPS Manuel: PAR.

Breslau, N., \& Kessler, R. C. (2001). The stressor criterion in DSM-IV posttraumatic stress disorder: An empirical investigation. Biol. Psychiatry, 50(9), 699-704.

Brewer, M., \& Miller, N. (1996). InterGroup relations (p. 191). Open University Press.

Charney, D. S. (2004). Psychobiological mechanisms of resilience and vulnerability: Implications for successful adaptation to extreme stress. Am. J. Psychiatry, 161(2), 195-216.

Chulov, M. (2013). Half of Syrian population "will need aid by end of year”. The Guardian, Web. 20 Dec. 2015. Retrieved from http://www.theguardian.com/world/2013/apr/19/half-syrian-population-aid-year

Coles, M., \& Heimberg, R. (2002). Memory biases in the anxiety disorders: Current status. Clinical Psychology Review, 22(4), 587-627. doi:10.1016/S0272-7358(01)00113-1

Dubow, E. P., Boxer, P., Huesmann, L. R., Shikaki, K., Landau, S., Gvirsman, S. D., \& Ginges J. (2010). J. Clin. Child Adolesc. Psychol., 39(1), 103-116. doi: 10.1080/15374410903401153

Eddy, B. (2012). Who are high conflict people? High Conflict Institute. Retrieved from http://www.highconflictinstitute.com/who-are-high-conflict-people

Eidelson, R., \& Eidelson, J. (2003). Dangerous ideas: Five beliefs that propel groups toward conflict. American Psychologist, 58(3), 182-192. doi:10.1037/0003-066X.58.3.182.

Farhood, L., \& Dimassi, H. (2011). Prevalence and predictors for post-traumatic stress disorder, depression and general health in a population from six villages in South Lebanon. Social Psychiatry and Psychiatric Epidemiology Soc Psychiatry Psychiatr Epidemiol,47(4), 639-649. doi:10.1007/s00127-011-0368-6

Farhood, L., Dimassi, H., \& Strauss, N. (2013). Understanding post-conflict mental health: Assessment of PTSD, depression, general health and life events in civilian population one year after the 2006 war in South Lebanon. Journal of Traumatic Stress Disorders \& Treatment, 2(2). doi:10.4172/2324-8947.1000103

Fao, B. F. (1993). Postturaumatic symtom scale-interview. International Society for First.

Michael et al. (2002). Structured Clinical Interview for DSM-IV-TR Axis I Disorders, Research Version, Patient Edition with Psychotic Screen (SCID-I/P W/ PSY SCREEN). New York: Biometrics Research, New York State Psychiatric Institute.

Foa, E. B. (2000). Psychosocial treatment of posttraumatic stress disorder. J. Clin. Psychiatry, 61(5), 43-48, 49-51.

Fisk, R. (2010). Freedom, democracy, and human rights in Syria. Independent, Tuesday 16 September. Retrieved from http://www. independent.co.uk/voices/commentators/fisk/robert-fisk-freedom-democracy-and-human-rights-in-syria-2080463.html

First, M., Spitzer, R., William, J., \& Gibbon, M. (2002). Structured Clinical Interview for DSM-IV AXIS I Disorders (SCID-I). In A. John Rush (ED.), Handbook of Psychiatric Measures (pp. 49-53) Washington, DC: American Psychiatric Association.

Forgas, J. (1982). Reactions to life dilemmas: Risk taking, success and responsibility attribution. Australian Journal of Psychology, 34(1), 25-35. doi:10.1080/00049538208254714 
Gebara, K. (2015). The Syrian crisis and its impact on Lebanon. Saint Joseph University. Retrieved from http://www.sciencespo.usj.edu.lb/pdf/The\%20Syrian\%20Crisis\%20\%20its\%20Implications $\% 20$ on $\% 20$ Lebanon $\% 20-\% 20 \mathrm{Kh}$ alil\%20Gebara.pdf

Gelkopf, M., Solomon, Z., Berger, R., \& Bleich, A. (2008). The mental health impact of terrorism in Israel: A repeat cross-sectional study of Arabs and Jews. Aeta Psychiatia Scandinavica, 117(5), 269-380.

Galea, S., Nandi, A., \& Vlahov, D. (2005). The epidemiology of post-traumatic stress disorder after disasters. Epidemiol Rev., 27, 78-91.

Gorst-Unsworth, C., \& Goldenberg, E. (1998). Psychological sequelae of Torture and organized violence suffered by refugees from Iraq: Trauma related factors compared with Social factors in exile. British Journal of Psychiatry, 172, 90-94.

Haddad, B. (2005). Left to its domestic devices: How the Syrian regime boxed itself in. Lecture presented at Real Instituto Elcano, Spain.

Haslam, S. A., \& Reicher, S. D. (2006). Stressing the group: Social Identity and the unfolding dynamics of responses to stress. Journal of Applied Psychology, 91, 1037-1052.

Hobfoll, S., Canetti-Nisim, D., Johnson, R. J., Palmieri, P. A., Varley, J. D., \& Galea, S. (2008). The association of exposure, risk, and resiliency factors with PTSD among Jews and Arabs exposed to repeated acts of terrorism in Israel. Journal of Traumatic Stress, 21(1), 9-21.

Hoffman, L., \& Beyond, F. (2011). Emotions affect cognitions: When emotions are strong our cognitive functions are profoundly affected. Psychology Today.

Hooper, L., Stockton, P., Krupnick, J., \& Green, B. (2011). Development, use, and psychometric properties of the Trauma History Questionnaire. Journal of Loss and Trauma, 16, 258-283. doi: 10.1080/15325024.2011.572035

Jacobson, L., \& Sapolsky, R. (1991). The role of the hippocampus in feedback regulation of the hypothalamic-pituitary-adrenocortical axis. Endocr Rev., 12(2), 118-34.

Jervis, R. (1976). Perception and misperception in international politics. West Sussex: Princeton University Press.

Jones, E., \& Nisbett, R. (1972). The actor and the observer: Divergent perceptions of the causes of behavior. In E. E. Jones et al.(Eds.), Attribution: Perceiving the causes of behavior. Morristown, N.J.: General Learning Press.

Joseph, S., Yule, W., \& Williams, R. (1993). Post-traumatic stress: Attributional aspects. Journal of Traumatic Stress, 6(4), 501-513. doi:10.1007/BF00974319

Karam, E., Mneimneh, Z., Dimassi, H., Fayyad, J., Karam, A., Nasser, S., ... Murthy, R. (2008). Lifetime prevalence of mental disorders in Lebanon: First onset, treatment, and exposure to war. PLoS. Medicine, 5(4), E61-E61. doi:10.1371/journal.pmed.0050061

Karl, A., Schaefer, M., Malta, L. S., Dörfel, D., Rohleder, N., \& Werner, A. (2006). A meta-analysis of structural brain abnormalities in PTSD. Neurosci. Biobe. hav. Rev., 30(7), 1004-1031.

O’keefe, J., \& Nadel, L. (1978). The hippocampus as a cognitive map. Oxford: Clarendon Press.

Khatib, L. (2014). Repercussions of the Syrian refugee crisis for Lebanon. Al-Hayat. Translated from Arabic. Carnegie-Middle East.

Khamis, V. (1993). Posttraumatic stress disorder among the injured of the Intifada. Journal of Traumatic Stress, 6, 555-559.

Khamis, V. (2005). Post-traumatic stress disorder among school age Palestinian children. Child Abuse and Neglect, 21, 81-95.

Kindt, M., \& Engelhard, I. (2005). Trauma processing and the development of posttraumatic stress disorder. Journal of Behavior Therapy and Experimental Psychiatry, 69-76. doi:10.1016/j.jbtep.2004.11.007

Kreidie, L. H., \& Monroe, K. R. (2002). Psychological boundaries of ethnic conflict: How identity constrained choice and worked to turn ordinary people into perpetrators of ethnic violence during the Lebanese Civil War. International Journal of Politics, Culture, and Society, 16(1), 5-36.

Lenzenweger, M. F., Lane, M. C., Loranger, A. W., \& Kessler, R. C. (2007). DSM-IV personality disorders in the National Comorbidity Survey Replication. Biol. Psychiatry, 62(6), 553-564. Retrieved from http://www.ncbi.nlm.nih.gov/pmc/articles/PMC2044500/

Lauterbach et al. (1997). Psychiatric management of neurological disease. Washington DC: American Psychiatric Press.

Macksoud, M., \& Aber, J. (1996). The war experiences and psychosocial development of children in Lebanon. Child Development, 67(1), 70-88. doi:10.1111/j.1467-8624.1996.tb01720.x

McPherson, H. (2003). Essentials of clinical psychopharmacology. Australian and New Zealand Journal of Psychiatry, 37, $249-250$. doi:10.1046/j.1440-1614.2003.t01-1-01139.x

Mollica, R. et al. (1992). The Harvard Trauma Questionnaire: Validating a cross-cultural instrument for measuring torture, trauma, and posttraumatic stress disorder in Indochinese refugees. The Journal of Nervous and Mental Disease, 180(2). 
Nader, K., Newman, E., Weathers, F., Kaloupek, D., Kriegle, J., \& Blake. ( 2012). Clinician administered PTSD scale for children and adolescents. The National Child Traumatic Stress Disorder.

Narrow et al. (2012). DSM-5: How reliable is reliable enough? The American Journal of Psychiatry, 169(1), 13-15.

Neria, Y., Nandi, A., \& Galea, S. (2007). Post-traumatic stress disorder following disasters: A systematic review. Psychological Medicine, 1-14. Cambridge University Press.

Neria, Y., Besse, A., Kiper, D., \& Westphal, M. (2010). A longitudinal study of Posttraumatic stress disorder, depression, and generalized anxiety disorder in Israeli citizens exposed to war trauma. Journal of Traumatic Stress, 1-9.

Neria, Y., Bravova, M., \& Hapler, J. (2010). Trauma and PTSD among civilians in the Middle East. PTSD Reseach Quarterly. 21(4).

OCHA. (2015). Updated Overview: 2015 Syria Response Plan and 2015-2016 Regional Refugee and Resilience Plan. https://docs.unocha.org/sites/dms/Syria/Overview\%20of\%202015\%20Response\%20Plans\%20for\%20Syria\%20Crisis_15032 2.pdf

Norris, F. H., Friedman, M. J., Watson, P. J., Byrne, C. M., Diaz, E., \& Kaniasty, K. (2002). 60,000 disaster victims speak: Part I. An empirical review of the empirical literature, 1981-2001. Psychiatry, 65, 207-239.

Pat-Horenczyk, R., Qasrawi, R., Lesack, R., Haj-Yahia, M., Peled, O., Shaheen, M., et al. (2009). Posttraumatic symptoms, functional impairment, and coping among adolescents on both sides of the Israeli-Palestinian conflict: A cross-cultural approach. Applied Psychology, 58, 688-708.

Pitman, R. K., Rasmusson, A. M., Koenen, K. C., Shin, L. M., Orr, S. P., Gilbertson, M. W., Milad, M. R., \& Liberzon, I. (2012). Biological studies of post-traumatic stress disorder. Nat Rev Neurosci., 13(11), 769-787. doi:10.1038/nrn3339

Reicher, S., \& Halsam, S. A. (2006). Tyranny revisited: Groups psychological well-being and the health of societies. The British Psychological Association. The Psychologist Forum.

Rothbaum, B. O., \& Schwartz, A. C. (2002). Exposure therapy for posttraumatic stress disorder. Am. J. Psychother, 56(1), 59-75.

Reicher, S., \& Halsam, S. A. (2006). Rethinking the psychology of tyranny. The BBC Prison Study. The British psychological Association.

Ruggiero, K. J., Del Ben, K., Scotti, J. R., \& Rabalai A. E. (2003). Psychometric properties of the PTSD Checklst-Civilian Version. Journal of Traumatic Stress, 16(5), 495-502.

Rodriguez, N., Steinberg, A., \& Pynoos, R. (1999). UCLA PTSD index for DSM IV. UCLA Trauma Psychiatry Service.

Rothbaum, B. O., \& Schwartz, A. C. (2002). Exposure therapy for posttraumatic stress disorder. American Journal of Psychotherapy, 56, 59-75.

Save the Children. (2014). Syrian refugee situation analysis of youth in Lebanon. Beirut: UN Refugee Agency (UNHCR).

Shaheen, K. (2014). Lebanon ill-equipped to handle mental-health issues of Syrian refugee children. The Washington Post. Retrieved November 4, 2015, from https://www.washingtonpost.com/world/middle_east/lebanon-ill-equipped-to-handle-ptsd -in-children-of-syrian-refugeees/2014/09/27/4b035b44-4406-11e4-9a15-137aa0153527_story.html

Seymour, C. (2003). Social psychological dimensions of conflict beyond intractability.

Stoessinger, J. (2010). Why nations go to war (International Edition 11e ed.). Boston, Massachusetts: Cengage Learning.

Syria Regional Refugee Response. (2015). UN Refugee Agency (UNHCR). Retrieved from http://data.unhcr.org/syrianrefugees/regional.php

Thabet, A. A., Abed, Y., \& Vostanis, P. (2004). Comorbidity of PTSD and depression among refugee children during war conflict. J. Child Psychol. Psychiatry, 45(3), 533-542.

The Guardian. (2013). Humanitarian crisis: Syria's nightmare. Retrieved from https://www.theguardian.com/commentisfree/2013 /sep/04/humanitarian-crisis-syria-nightmare-editorial

Tversky, A., \& Kahneman, D. (1974). Judgment under uncertainty: Heuristics and biases. Science, 185(4157), $1124-1131$. doi:10.1126/science.185.4157.1124

UNHCR Syria Regional Refugee Response. (2015). Retrieved from http://data.unhcr.org/syrianrefugees/country.php?id=122 Waller, J. (2007). Becoming evil: How ordinary people commit genocide and mass killing (2nd ed.). Oxford University Press. Weiner, B. (1974). Achievement motivation and attribution theory. Morristown, N.J.: General Learning Press.

Weiner, B. (1986). An attributional theory of motivation and emotion. New York: Springer-Verlag. 